\title{
The Dynamics of Good and Evil in Leadership: A Study of Shakespeare's Macbeth and Kant's Religion within Boundaries of Mere Reason
}

\author{
Shahida Khan \\ Indian Institute of Management, India
}

\begin{tabular}{|c|c|}
\hline ARTICLE INFO & A B S T RACT \\
\hline $\begin{array}{l}\text { Keywords: } \\
\text { ethics, } \\
\text { evil, } \\
\text { good, } \\
\text { leadership, } \\
\text { leading. }\end{array}$ & $\begin{array}{l}\text { Understanding the nuances of good and evil in literary representation } \\
\text { has been a trend in the neo-academic circle. Within the framework of } \\
\text { Leadership Studies, the present paper locates Shakespeare's Macbeth } \\
\text { (1606) central to the understanding of the concepts of good and evil in } \\
\text { leading. The first section critically introduces the concepts of good and } \\
\text { evil and their place in leading and Kant's view on good and evil. The } \\
\text { second section gives a short summary of the plot of the play Macbeth. } \\
\text { In the third and fourth section I argue that Macbeth is a potential text } \\
\text { for an emphatic understanding of good and evil in leading; I highlight } \\
\text { the ethical dimension in leading and leadership. It not only argue } \\
\text { that the character of Macbeth can be represented as prototypes } \\
\text { of understanding the dynamics of righteous and evil leaders, I also } \\
\text { suggest that teaching ethical issues of leadership can be strengthened } \\
\text { by an analysis of the character of Macbeth. The last section draws } \\
\text { parallels with real-life case bringing out the consequences of unethical } \\
\text { leading. }\end{array}$ \\
\hline
\end{tabular}

$\mathrm{T}$ The concepts of good and evil have long been a matter of debate and discussion among philosophers, theologians, sociologists, psychologists and humanists, and each discipline of studies has something unique to offer towards the understanding the nature of good and evil. For example, in Theology the terms "good" and "evil" are explained in terms of their relation to God and Devil. Theologians discuss the problem of evil in relation to divine perfection. Philosophical enquiries into the field have opened up discussions concerning the relative nature of the concepts through the classical age to the modern period. For Plato, the good is not a matter of opinion, but an object of knowledge. Knowledge of good and evil is best fruit of the tree of knowledge, "let each one of us leave every other kind of knowledge" (Jowett, 1970; 623). Socrates says at the end of Plato's The Republic (380 BC): "and seek and follow one thing only," and that is "to learn and discern between good and evil" 
(Jowett, 1970; 623). Aristotle's view on the nature of good and evil is found in Nichomachean Ethics (350 BC). In this treatise he points out that ethics or any science that deals with good and evil can have as much precision as mathematics. Indefiniteness and even a certain amount of relativity occur when the principles are applied to particular cases.

The terms "good" and "evil," Spinoza writes in Ethics (1677), indicate "nothing positive in things considered in themselves, nor are they anything else than modes of thought... One and the same thing may at the same time be good and evil or indifferent" (Shirley, 1992; 163). Such conclusions may come only according to the person who makes judgment of it. Therefore, Spinoza defines 'good' as "that which we certainly know is useful to us" (1992; 164). Apart from society he says: "There is nothing which by universal consent is good or evil, since everyone in a natural state consults only his own profit" (1992; 164). The same idea echoes in Montaigne's essay that says: “... that the taste of good and evil depends in large part on the opinion we have of them" (Frame, 1958, 34). The impact of Montaigne is seen on Shakespeare as Hamlet comments: "There is nothing good or bad but thinking makes it so" (2.2.250). Thus according to Spinoza, only when men together in a civil society under law can it be "decided by universal what is good and what is evil" (Shirley, 1992; 175). Concepts such as good and evil and what is good and what is bad for a society are all relative concepts and ideas, and they are subject to change according to time, place and societal developments. Thus, what is punishable according to the rules of a society is generally considered bad or evil. In general, we estimate or judge things according to our own condition and the way things affect us. Thus, keeping in view Socrates' argument in Theaetetus - "in which all things are said to be relative"-good and evil become relative terms and they vary according to conditions and situations (Campbell, 1861; 38).

The Oxford English Dictionary (1966) defines evil as the antithesis of good in all its principal senses. But in the common use, the term 'evil' is denoted as something bad, vicious, ill, wicked and the phrase has negative connotations like the expression of disapproval, dislike or disparagement (332). The word goes beyond these negative connotations of 'badness' and has a wide range of meaning. It cannot be defined as a single idea but it stands as a broad concept housing divergent views by philosophers and theologians on its nature and characteristics. Ervin Stuab in The Roots of Evil: The Origins of Genocide and Other Group Violence (1989) discusses evil as something that cannot be a defined as a fixed entity:

Scientific concept with an agreed meaning, but the idea of evil is part of a broadly shared human cultural heritage. The essence of evil is the destruction of human beings. This includes not only killing but creation of conditions that materially or psychologically destroy or diminish people's dignity, happiness, and capacity to fulfill basic material needs.... By evil I mean actions that have such consequences (25).

Is evil an individual entity? Is it a group entity? Or is it characterized by the absence of 'goodness' or is it absence of 'goodness' in individual and society? Philip Zimbardo in The Lucifer Effect: Understanding How Good People Turn Evil (2007) suggests that "evil consists in intentionally behaving in ways that harm, abuse, demean, dehumanize, or destroy innocent others-or using one's authority and systematic power to encourage or permit others to do so on your behalf" (5). Kant's concept of 'radical evil' proposes evil as "an invisible enemy, one who hides behind reason and hence [is] all the more dangerous (Wood and Giovanni, 1966; 77). Thus, the scope of evil extends to anything 'wrong' that may lead to serious personal and social consequences. Yet defining 'evil' is not at all an easy phenomenon; the scope of it is ever arching and ever broadening. In most cases moreover, central to evil is human action or deed. The Catholic Encyclopedia for instance 
discusses evil from the point of view of human welfare and proposes that evil is "what ought not exist" (Sharpe, 1909; n. pag.). In this paper I have discussed the character of Macbeth to bring out the dynamics of good and evil and how great leaders get dismantled due to unethical leading in context of the evil discussed by Kant in Religion within Boundaries of Mere Reason.

\section{METHODS}

The research method consists of interpretation of primary texts by William Shakespeare in the light of issues in leadership put forward in the present decades. I also use historical, philosophical and biographical texts in order to establish that Shakespearean tragedy Macbeth and Kant's Religion within Boundaries Mere Reason are helpful in understanding problems in leading and in drawing parallels from modern-day scenario. I support my argument with a significant number of texts, critical essays, and books on Leadership Studies and also criticism on Shakespearean plays.

\section{Macbeth: The Story}

Macbeth was written by William Shakespeare between 1603 and 1607. It is one of the greatest tragedies ever written, the play was based on the true story of Mac Bethadmac Findlaich, King of Scots in the 11th century. It is known that Shakespeare wrote Macbeth as a celebration of King James accession to the throne in 1603. The plot of Macbeth is set in medieval Scotland. Macbeth is portrayed as a loyal and brave general in King Duncan's army.

The play begins with the three witches meeting Macbeth and his fellow soldier, Banquo returning from a successful battle. They greet him as the "Thane of Glamis", "Thane of Cawdor" and "King" hereafter. They also prophecy that the future heirs of the throne will be descended not from Macbeth but from Banquo. The witches disappear, and a messenger from the King arrives announcing that Macbeth has been named Thane of Cawdor, thus fulfilling the first part of the prophecy. These predictions by the witches arouse in Macbeth the desire to be king either by fate or effort.

Upon hearing King Duncan's declaration that he is nominating his son, Malcolm, as heir to the throne disillusions Macbeth. He gets anxious yet dares not take up unethical means to gain the crown, but with the provocation of Lady Macbeth he decides to murder King Duncan and take away crown by force. He realizes King Duncan's stay in his castle is an excellent opportunity to murder him. Macbeth stabs the sleeping King Duncan, and two guards are framed for the crime. The next morning, Macduff, a noblemen, discovers the body of the King. The King's son, Malcolm, flees to England, and the lords of the kingdom vow to avenge the King's murder. Macbeth is appointed King, but with the witches' prophecy in mind, he arranges for the murder of Banquo and his son, Fleance.

Although Banquo is killed, the hired assassin does not succeed in killing Fleance. Macbeth suffers on the thought of not having his heir succeeding the throne after him and he goes to the witches again to know his future. The witches share new visions with him and warn him against Macduff, and assure him that he can never be killed by "one of woman born" and he need not fear till he sees Birnam Wood begin to move. These manipulated predictions lead Macbeth to think that he is safe from harm, although the witches still show that Banquo's descendants will ascend the throne. When Macbeth learns that Macduff has fled the country to join Malcolm, he orders execution of his family.

One after another Macbeth and Lady Macbeth engage in sins. Lady Macbeth goes insane by the guilt of the sins committed and kills herself. Macbeth continues with the evil he has unleashed by his sinful activities. Macduff and Malcolm advance with an army to challenge Macbeth, cutting down the branches of Birnam Wood to disguise their number. Macbeth remains confident 
of his victory till Macduff tells him that he was "from his mother's womb, untimely ripped," and in face to face combat Macbeth is defeated. Malcolm becomes the King of Scotland.

\section{RESULTS AND DISCUSSION}

Immanuel Kant in his book Religion within Boundaries of Mere Reason (1793) presents human nature to be 'radically evil' (Wood and Giovanni, 1966; 69). He asserts in this treatise that the root of evil is corrupt 'moral orientation' and an 'evil disposition' (1966, 95). Kant's view on evil, moreover, has often been questioned and is found to be contradictory to the Christian doctrine of 'Original Sin' that claims evil to be inherited. Kant argues that the root of evil is human will and the choice of people's action. Instead of choosing rightness, it is human nature to choose what accomplishes the ends most (1966, 87). Therefore, Macbeth's evil actions can be understood as result of the choices he makes-inspired by his own desire to attain kingship and gather supreme power. He engages in evil because it promises him power, position and status.

Kant writes that human beings are radically evil; this is because the propensity towards evil is deeply ingrained in human nature and it corrupts our power of choice at its very root $(1966,98)$. The evil deed cannot completely be attributed to the outer forces; the temptation of the witches or the prophecy alone is not responsible in corrupting the character of Macbeth. Rather, according to Kant's explanation, it is subjugated in human mind itself. Kant further explains that the fundamental principle of choice depends on our satisfaction, i.e., we make the satisfaction one of our ends taking priority in the will of our actions. We thus inculcate in ourselves a propensity to make exceptions to the demand of the categorical in circumstances when such an exception seems to be in our favour. He further suggests that overcoming radical evil requires a "change of heart," i.e., a reordering of our fundamental principle of choice that we are responsible for. Effecting such a change, however, leaves unsettled our moral culpability for those choices that are made under the inverted maxim evil.

Thus, metaphorically, Macbeth's reaction after hearing the prophecies by the witches hints at his intentions. He had been contemplating on regicide and the witches encourage him to move ahead with the deed. Banquo remains confused to see Macbeth's reaction to the prophecy; in fact the chances of being a king should have made him happy. Why is then Macbeth scared of "royal hope" (1.3.54)? Is it because Macbeth had been contemplating on usurpation and the witches are representative of the demonic forces within him that expose his deepest desire? In spite of the mental turmoil and ethical dilemma, Macbeth chooses to embrace the evil act because the endgoal hopes to bring him power and glory. The love of self is so great that unnaturalness of regicide is forgotten.

The problem of good and evil has ever perplexed all human civilizations. Why does a character or person choose to act evil when she/he is aware of its nature? How good is it to be virtuous in a world where everybody is competitive and everyone wills to progress at all point of time? How in other words does a person, in spite of knowing the consequences of evil, choose the wrong path? Literary representations remain central in questioning and understanding the concepts of good and evil and show the way a character or situation could be balanced. The classical notion of tragic gaiety also answers part of question. Hence, in what follows we explore the framework within which Macbeth introduce us to evil and we initiate a discussion furthering their scope in the present-day business world where unethical leadership has been a matter of concern. I argue that Macbeth is potential texts for an emphatic understanding of the concepts in leading. I not only argue that the characters of Macbeth can be presented as prototype of understanding the dynamics of righteous and evil leaders, we also 
suggest that teaching ethical issues of leadership can be strengthened by an analysis of the character of Macbeth.

Whether philosophically, literally or metaphorically, the duel between good and evil has been constantly yet dramatically represented in seventeenth century writing. In most cases, an external force remains central to 'temptation' or withdrawing a man of action from the righteous act. The feminine also is portrayed as an instrumental factor in accelerating the evil act. These are not just stereotypes that the seventeenth century contributed to emphatically, it has also been a way of judging the male-centred humanist universe. The concept of evil, in most cases, has been gendered and as scholars we need to see the construction of the external forces that remain operative in such cases as well the evil within us. For example in this sonnet by Shakespeare he plays out the age-old conflict between good and evil taking woman as an embodiment of evil.

The better angel is a man right fair, The worser spirit a woman coloured ill. To win me soon to hell, my female evil, Tempteth my better angel from my side, And would corrupt my saint to be a devil, Wooing his purity with her foul pride. (Shakespeare, Sonnet 144)

They focus on the beauty of a lady as evil because it encourages the man to deviate from the path of righteousness. These dark ladies are seductresses who take the fair man away from the path of goodness. In the sonnets, the women herself is personified as evil-as the bad angel-who is on the side of the devil and is responsible for all the world's woes. Lady Macbeth is also dramatically represented in the same light, who seduces Macbeth and lures him into his destruction.

At the outset Macbeth and Lady Macbeth plan the murder of the King for their personal gain, i.e., for kingship. The tragedy of the Macbeths is that they had no son to inherit the kingdom.1 They lack the imagination to foresee and understand the consequences of their nefarious deed. Similarly, Doctor Faustus succumbs to the temptations of evil and fails to foresee the consequences of his deeds. He sells his soul to Lucifer for twenty-four years of luxurious life on Earth. The internal conflict is dramatically represented as a duel between the Good Angel and the Bad Angel throughout the play. Marlowe's The Tragicall History of the Life and Death of Doctor Faustus (1604) personifies good and evil in the form of Good Angel and Bad Angel. The play portrays the conflict between the Good Angel and the Evil Angel trying to influence Faustus' actions inviting him to discourse reason and finally evil wins the contest:

Good Angel: Sweet Faustus, leave that execrable art.

Faustus: Contrition, prayer, repentancewhat of them?

Good Angel: Oh, they are means to bring thee unto heaven.

Evil Angel: Rather illusions, fruits of lunacy, That makes men foolish that do trust them most.

Good Angel: Sweet Faustus, think of heaven and heavenly things.

Evil Angel: $\quad$ No Faustus, think of honour and of wealth. (452-9)

Faustus falls a prey to the temptation of the Bad Angel, embraces the Devil for material gains but by the end of the play he is found repentant and disillusioned. There remains however no way to retreat. He is damned eternally and his soul suffers torments of Hell. The play serves as a warning to the Renaissance spirit of insatiable thirst for knowledge, power and position. It also serves as a hint towards the questions of ethics and morality of people with power and knowledge.

In the first part of the play, Macbeth acts as a murderer killing King Duncan; in the second part he becomes a tyrannical ruler; and by the end of 
the play, the evil within him is unleashed and he goes on murdering people whom he perceived as a threat. First in this series remain Banquo and Fleance. Banquo is a threat for him on account of two reasons; firstly, according to the prophecy by the weird sisters it is Banquo who would father the future king: "Thou shalt get kings, though thou be none" (1.3.65) and secondly, Banquo is equally aware of the prophecy and suspects him of murdering the King: "Thou has it now, "King, , Cawdor, Glamis, all, / As the weird women promised, and, I fear, / Thou play'dst most foully for 't... It should not stand in thy posterity" (3.1.14). Banquo's murder would free him of all the worries of being exposed. Macbeth is afraid of Banquo's presence because he finds him to be his competitor. He is aware of the fact that Banquo is a man of royal nature, dauntless courage, and wisdom and can prove to be a potential threat for him: "Our fears in Banquo / Stick deep; and in his royalty of nature / Reigns that which would be fear'd: 'tis much he dares; / And to that dauntless temper of his mind / He hath wisdom that doth guide his valour /... there is none but he / whose being I do fear" (3.1.51-55). Therefore, he decides to get him and his son murdered. The murder of Fleance ends all the speculations regarding the succession to the throne according to the prophecy. But Fleance fortunately escapes the murderers attack leaving Macbeth unsatisfied and doubtful.

Macbeth's suffering on personal fronts after the murder is pitiable. He suffers tremendously. He is compelled by Lady Macbeth to commit regicide though he wanted to retreat from it. After murdering Duncan, he feels guilty and finds the act extremely sinful similar to King Claudius, and that is why he says: "But wherefore could not I pronounce 'Amen'? / I had most need of blessing, and 'Amen' / Stuck in my throat" (2.2.33-35). Not only this, he is so ashamed of himself and the act that he refuses to acknowledge himself: "To know my deed, 'twere best not know myself" (2.2.75). $\mathrm{He}$ is filled with grief and remorse for having committed the act and realizes that by murdering Duncan he has actually killed his inner self, his innocence, peace of mind, and significantly he is deprived of 'sleep' which is like a balm for an agitated mind:

Macbeth does murder sleep, the innocent sleep,

Sleep that knits up the ravell'd sleeve of care, The death of each day's life, sore labour's bath, Balm of hurt minds, great nature's second course,

Chief nourisher in life's feast (2.2.38-42)

It is this expression of repentance and remorse that makes the character of Macbeth human. Macbeth's journey towards approaching evil remains slow initially; it passes through different stages. And Macbeth justifies it on many grounds, viz., the nature of his ambition, the futuristic view of the prophecies and through the involvement of external forces that led him to commit the fatal error of killing the King. The frailty in the character of Macbeth is exposed when he succumbs to the temptations offered by the three witches. Prior to the meeting with the witches, he was held in reverence among his colleagues and the King admired his manners and skills. Macbeth was loyal till he was not lured by the witches and was not aware of the future. Disloyalty, however, is unimagined till he was seduced by the prophecies of the witches and until the first prophecy is materialized. As Macbeth crosses the first boundary and proffers the first title, his character unsettles much on his personal and professional fronts. On the professional front, it is the desire to achieve limitless power of a King; on the political realm comes agitation when he hears Malcolm is declared prince of Cumberland and hence a successor to the throne. These events unsettle much in the character of the principal subject and failing to predict what future holds for him, he surrenders to materialize the second prophecy. There, constructed as negative, this realm of personal gain unsettles much on personal 
and professional spaces. Failing, here constructed as immoral, to achieve a status initially, Macbeth succumbs to his personal realm, the plan of plotting the murder of the King. Macbeth is agitated when King Duncan declares Malcolm to be Prince of Cumberland and successor to the throne. $\mathrm{He}$ believes:

The Prince of Cumberland! That is a step On which I must fall down, or else o'er leap. (1.4.48-49)

According to Kant, our propensity to evil comes in three different forms, which differ in grade but not in type, as each form is but a different manifestation of the same evil moral orientation (1966, 78). The first grade refers to be frailty of human nature which means when it comes to actually living up to our moral values. Even when we have recognized ideally what we ought to do, when it comes implementing this in practice, especially when it is not to our advantage, we often find our moral commitments too frail to trump other interests $(1966,80)$. This is what Macbeth is engaged into. He realizes the cruelty of the act, yet he commits the act of murdering because he could not detach himself from love of self, his love for the title and the power that kingship promises. One way of interpretation could be it was with the instigation of his wife that he moves ahead with the evil act. She acts as a temptress and an ally to the witches who lure him into evil. It cannot be denied, however, that it is because of his personal choice and will to engage in evil that Macbeth succumbs to commit all the crimes.

Shakespeare has presented Lady Macbeth, a loyal partner to Macbeth, who encourages him towards self-promotion. She advises him to disguise his true intentions upon the arrival of the King as: "Look like the time; bear welcome in your eyes, / Your hand, your tongue: look like the innocent flower, / But be the serpent under't" (1.5.62-64). She has been his guiding force, acting like a true paramour, but in the end we find Lady Macbeth who tried hard to be strong and full of evil could not bear the burden of the guilt of the sin. She turns mad and according to Freud, it was the loss of purity of mind and heart that she rushed to wash her hands. Freud writes: "The washing was symbolic, designed to replace the physical purity by the moral purity which she regretted having lost. She tormented herself with remorse for conjugal infidelity, the memory of which she had resolved to banish from her mind" (1959; 322). Further Freud asserts that there were no signs of remorse or internal conflict in Lady Macbeth right from the beginning, but it was only after becoming queen she feels disappointed and disillusioned and at one point she says: “... Nought's had, all's spent, / Where our desire is got without content. / 'tis is safer to be that which we destroy / Than by destruction dwell in doubtful joy" (3.2.4-7). Freud explores the tragedy of Macbeth more in terms of father-son relationship and attributes the cause of mental disorder in Lady Macbeth to be her childlessness. It was only the passion and ambition responsible for Lady Macbeth's pitiable state. She fails to understand her true nature. She resolves to fill in him her spirit and determination so that there can be no impediments in her husband's progress. She exhibits firm determination in achieving what has been promised to her husband by all ways and means:

Hie thee hither,

That I may pour my spirits in thine ear;

And chastise with the valour of my tongue

All that impedes thee from the golden round.

(1.5.25-28)

In another soliloquy in the same act when she receives the news of King Duncan visiting their castle, she determines to be strong and invokes the spirits to deprive her of womanly qualities of love, mercy, humility and wants no impediments in her way. Here, she represents malevolent power who subdues her feminine and maternal instincts for power and glory. She invokes evil forces to take way the softer and emotional feelings and fill 
in her with cruelty-an attempt to harden herself psychologically to prepare her husband for the deed:

\section{Come, you spirits}

That tend on mortal thoughts, unsex me here, And fill me from the crown to the toe top-full Of direst cruelty! Make thick my blood; Stop up the access and passage to remorse, ... come to my woman's breast,

And take my milk for gall... (1.5.38-46)

Kant argues propensity to evil is due to the impurity of the human heart and in its tendency to mix pure and impure incentives. The true motives for acting often or always are opaque, even to ourselves, and we find it difficult to ever act for the sake of moral law (Wood and Giovnni, 1966; 97). Lady Macbeth's intention in instigating Macbeth in killing Duncan seems to be motivated by her own desire to achieve the status of queen because Holinshed's account writes Macbeth's career is influenced by his ambitious spouse who encourages him towards regicide: "'lay sore upon him to attempt' regicide as she that was verie ambitious, burning in unquenchable desire to beare the name of a queene" (Braunmuller, 1997; 14).

In the last act, Macbeth realizes that there is no escape from what he has done and commands more criminal and selfish deeds. Upon hearing the news of his wife's mental state, he shouts at the doctor to cure her: "Cure her of that / Canst thou minister to a mind diseased, / Pluck from the memory a rooted sorrow" (5.2.40-42). He realizes that what is done rashly_- "done the deed"-of self promotion at his wife's instigation cannot be undone: "What's done, is done" (3.2.11-12). Lady Macbeth's death makes him reflect upon the nature of life and death. He is repelled by the news of his wife's death and finds his own life futile and worthless: "To-morrow, and to-morrow and to-morrow, / ... / Life's but a walking shadow, a poor player / That struts and frets his hour upon the stage / And heard no more: it is a tale / Told by an idiot, full of sound and fury, / Signifying nothing" (5.5.16-26).

This soliloquy expresses the intense spiritual suffering in Macbeth. He hints at the pointless existence of man on earth. By this time he realizes the fruitlessness of his ambition. The ambition for which he had sold his soul like Doctor Faustus has brought forth only sorrow, madness and death. He is disillusioned and understands the trap he has been put into by the weird sisters, yet his martial spirit forces him to move ahead with the war and like a valiant soldier he plans to fight: "They have tied me to a stake: I cannot fly, / But, bearlike, I must fight the course" (5.7.1-2). He derives courage to move ahead further from his despair and depravity: "I have almost forgot the taste of fears" (5.5.9). The courage to move on comes from his realisation that his ambition is nothing but a delusion, fostered by the seductive deceptions of the three witches.

By the end of the play, Macbeth is repentant and disillusioned for having committed the crime against humanity. In fact he acknowledges that Duncan is resting in peace, whom he has murdered: "After life's fitful fever he sleeps well; / Treason has done his worst: nor steel, nor poison, / Malice domestic, foreign levy, nothing / Can touch him further" (3.2.23-26). And on the other hand, he is going through a mental and psychological turmoil for committing the murder: "O full of scorpions is my mind, dear wife! / Thou know'st that Banquo, and his Fleance, lives" (3.2.36-37). His suffering is beyond endurance and has reached to the point when he finally realizes that the evil he has indulged into cannot be corrected, "Things without all remedy / Should be without regard; what's done, is done (3.2.11-12). In the same manner Claudius is also repentant for breaking the sacred bond of familial relations. He tries to seek forgiveness and states: "My words fly up, my thoughts remain below: / Words without thoughts never to heaven go" (3.3.98-99). It all goes in vain because he still desires kingship. 


\section{MANAGERIAL IMPLICATIONS}

Macbeth represents evil, tyranny and unethical leading whereas Duncan and Malcolm represent goodness and serve to be role model for ethical leadership. Macbeth's struggle with his inner desire to garner power for self is a lesson to understand the use of power and its abuse. Macbeth uses power to lead by force and Duncan and Malcolm use power to restore peace and tranquility in the kingdom. King Duncan and Malcolm present prototype of good leaders. In the play good and evil are represented in the form of Duncan and Malcolm, and Macbeth and Lady Macbeth respectively. Duncan is hence represented as 'gracious' (3.1.66) and upon his death "renown and grace is dead" (2.3.101); after his death, Malcolm takes the charge of restoring peace and tranquility in Scotland.

King Duncan is portrayed as a kind and generous ruler, who keeps his subjects happy and rewards them justly for their services. 2 He honours and rewards Macbeth for his bravery and feats at war. King Duncan represents an ideal leader who practices transformational leadership. He praises and calls Macbeth to be, "worthiest cousin" and honours him declaring that he deserves more than what has been bestowed upon him [Macbeth] when compared to his acts of bravery and loyalty for the state: “... Would thou hadst less deserved, / That the proportion both of thanks and payment (1.4.18-19). Duncan is portrayed as a leader who was like a father figure for his followers. He takes care of his subjects, nurtures them and takes responsibility of their growth and progress. He is just and praises Banquo equally for his bravery at the battlefield:

I have begun to plant thee, and will labour To make thee full of growing. Noble Banquo That hast no less deserved, nor must be known. No less to have done so, let me enfold thee. And hold thee to my heart. (1.4.28-32)

King Duncan serves to be opposite of Macbeth in context of leadership and leading.3 When Duncan announces Malcolm, his eldest son to be the successor to the throne, he makes very clear that his subjects are equally dear to him and will receive favours and benefits according to their abilities:

Our eldest, Malcolm, whom we name hereafter. The Prince of Cumberland; which honour must. Not unaccompanied invest him only, But signs of nobleness, like stars, shall shine On all deservers. (1.4.38-42)

Malcolm also exhibits qualities of a wise leader. Instead of grieving over the loss of his father and his inherited throne, Malcolm acts intelligently and decides to leave for his safety and takes the right decision in taking refuge in England, where he is not only treated according to his dignity but also is extended help. Heeding his brother Donalbain's advice-“there's daggers in men's smiles" (1.4.136)—he wisely tests the loyalty of all those in his confidence. For example, he tests Macduff's loyalty in Act IV, scene iii, by pretending to be devoid of all the virtues that a good leader should possess. When Macduff expresses his grief over the pitiable state of Scotland, Malcolm swears to his own virtues and loyalty. By this time he is convinced that Macduff can be trusted as he has passed the loyalty test.

Malcolm also proves to be a good strategist as he commands the soldiers to use natural surroundings of Birnam Wood to disguise the attack on Macbeth at Dunsinane. Prior to the attack, Malcolm comments on Macbeth's lack of loyal followers, except for those "whose hearts are absent too" (5.4.14). Macbeth is hasty in taking decisions. Whenever he doubted someone, he would have him murdered. Contrarily, Malcolm remained patient in testing his foes and then concluded about his trust. Malcolm also exhibits the virtues of his father and takes over the crown of Scotland after Macbeth is killed. His speech upon his victory reflects that now Scotland will be 
a safe place: "As calling home our exiled friends abroad / That fled the snares of watchful tyranny" (5.9.33-34). Further, he announces rewards for his subjects who were loyal to him, "My thanes and kinsmen, / Henceforth be earls, the first that ever Scotland / In such an honour named" (5.9.29-31). This marks the end of the evil and tyranny that the rule of Macbeth had unleashed. In the same way Prince Hamlet becomes instrumental in ending the tyrannical rule of Claudius. The play ends with catastrophic death of all major characters and young Fortinbras is announced as the new King of Denmark.

Macbeth portrays the age-old conflict of good and evil, between conscience or ambition and ethics. It thus dwells upon the age-old philosophical question: can morals be sacrificed for ambition? And what happens when ambition becomes personal. Being ambitious is important for leaders for the orgainsational growth and development. But when this ambition becomes personal as in the case of Macbeth, it leads to serious consequences. An ideal leader shares his vision with his followers and does not keep it as a secret. In the present situation we do not have usurpers in the strictest sense of the term, but we have ample of instances when leaders have used power for fulfilling personal ambition, for self promotion and the result has been dangerous and sometimes catastrophic. One of the recent cases that has emphatic catastrophic consequences is B. Ramlinga Raju's unethical leading of Satyam Computers.

\section{Real life issues in unethical leading}

Satyam Computers (estd.1987), once India's fourth largest software service company, plunged into a turmoil after Ramlinga Raju-the founder and Chairman until January 2009-stunned the world with his confession of cheating more than six million shareholders. A man who started from an ordinary position and rose to create Satyam Computers, known to the world for his entrepreneurial skills, is now known as the perpetrator of the country's biggest corporate fraud named "India's Enron" (Caliyurt and Idowu, 2012). After being arrested and sent in Hyderabad's Chanchalguda jail on a number of charges including cheating, embezzlement and insider trading, Raju was granted bail on 18 August 2010. A botched acquisition attempt involving Maytas in December 2008, led to a plunge in share price of Satyam. In January 2009, Raju indicated that Satyam's accounts had been falsified over a number of years. He admitted to an accounting dupery to the tune of 7000 crore rupees and resigned from the Satyam board on 07 January 2009 (Wheelen and Hunger, 2009). In a stunning 5-page letter detailing years of financial deception at the firm he founded, Satyam Computers Services Chairman Ramalinga Raju brought an illustrious corporate career to an undignified end.

The case of Ramlinga Raju appears to be that of a tragic hero whose fall from grace arouses sympathy and leaves us in disbelief. A leader of par excellence who is given the credit of developing Hyderabad into an IT hub that brought thousands of jobs in the region, working for Satyam was once considered special in Hyderabad. Bill Gates and other corporate dignitaries often visited the region and marveled at the work being accomplished by the company. Different heads of states including former President Bill Clinton visited the campus. Parents would forbid their children to work elsewhere because they felt it was their duty to pay tribute to Raju for what he had done for the people of Hyderabad (Cohen, 2007). He was an icon for the community, and numerous books on Satyam style of leadership have been documented (Fernando, 2009).

As per close associates of the company Ramlinga Raju was humble, soft spoken and a man of highest integrity (Cohen, 2010). What went so wrong that he had to put on stake everything he had painfully earned? Earlier to the scandal, Ramlinga Raju was termed by media and various eminent people as a visionary, global business leader and a thinker 
(Cohen, 2007). He is a management graduate from Ohio State University and also an alumnus from Harvard Business School. He served as contributor to policy formulation, Chairman of NASSCOM (2007), member of National Executive Councils of Confederation of Indian Industry and the Federation of Indian Chambers of Commerce and Industry.

He also served on the boards of several educational, research and non-profit institutes including Harvard Business School (Regional Advisory Board), Indian School of Business, and the Administrative Staff College of India. He was also instrumental in programmes dealing with development of society and providing opportunities to the underprivileged by setting up institutions such as the Satyam Foundation that dealt with urban transformation, Byrraju Foundation that dealt with rural transformation, and Emergency and Management Research Institute (EMRI) that provided emergency response services across India. For his positive contribution towards societal development and economic growth, he was bestowed with many awards and honours. For example, in 2002 he was awarded "Corporate Citizen of the Year" during Asian Business Leadership Summit held in Hong Kong. He was also named as the 'IT Man of the Year' by Dataquest in 2001 and conferred the "Entrepreneur of the Year Award" by Ernst and Young, India in 2007. With such an outstanding career and impeccable reputation, Ramlinga Raju shocked the world with his confession of forgery in the accounts of Satyam Computers. He had been manipulating the company's accounts for seven years. His letter written to the board of directors certainly was more of a confession of crimes which in fact started as marginal manipulation but turned out to be devastating. He justifies the action to save the company from take-over:

The gap in the Balance Sheet has arisen purely on account of inflated profits over a period of last seven years (limited only to
Satyam standalone, books of subsidiaries reflecting true performance). What started as marginal gap between actual operating profit and the one reflected in the books of accounts continued to grow over the years. It has attained unmanageable proportions as the size of the company operations grew significantly...every attempt made to eliminate the gap failed. As the promoters held small percentage of equity, the concern was that poor performance would result in a take-over, thereby exposing the gap.

Who can believe that this was the same man Ramlinga Raju, the founder of Satyam School of Leadership in 2005 with the vision of expanding the entrepreneurial energy at Satyam to help keep pace with the ever changing global business context who could fall into such a catastrophic end? Ed Cohen had been recruited to build the leadership centre. The strategic intent behind this project was to nurture and grow leaders who could respond to real-time situations, be consistent in decision making and thus delight stakeholders, and be able to work collaboratively in a globallynetworked environment (Cohen, 2010).

The act of fraud by Ramlinga Raju was equally disturbing for the employees working in the company and their families. The mental trauma faced by them is beyond expression. The uncertainties and doubts regarding the future of the company and their position in it were of serious concern. But it is not only Ramlinga Raju who should be blamed for unethical practice, the governance of the board of members is also questionable (Wheelen and Hunger, 2009). We cannot overlook the fact that Ramlinga Raju not only accepted his mistakes in the whole scandal but also suggested measures that should be taken immediately at this critical hour. His appeal to the Satyamites to stand united shows his concern for his followers:

I have promoted and have been associated 
with Satyam for well over twenty years now. I have seen it grow from few people to $53,000 \ldots$ I sincerely apologize to all Satyamites and stakeholders, who have made Satyam a special organization, for the current situation. I am confident they will stand by the company in this hour of crisis... I fervently appeal to the board to hold together to take some important steps... Merrill Lynch (now Bank of America) will stand by the company at this crucial hour... I am now prepared to subject myself to the laws of the land and face consequences thereof.

He does echo Macbeth here, who hates killing Duncan on moral grounds yet it was the 'vaulting ambition' that forced him to regicide. Raju's fear of the company's take-over forced him to fraud the company's accounts. The scandal has many versions; for example Kinshuk Nag in The Double Life of Ramlinga Raju: The Story of India's Biggest Corporate Fraud (2009) says that at the heart of the scandal lay IT baron's craving for land (his family's traditional business). To satisfy it, Raju pawned his shareholding in Satyam as well as in his real estate company, Maytas Infra Limited. He allegedly siphoned off funds from both the companies. In an elaborate cover up, Raju also duped Satyam's account books to inflate its revenue and profits, to increase the value of its shares. Raju was able to do this for eight years until the recession hit in 2008 and the bubble blew in his face. Bhupesh Bhandari's The Satyam Saga (2009) highlights Ramlinga Raju's political links with the then chief minister of Andhra Pradesh N. Chandrababu Naidu and traces the origin of the scam. The book raises issues such as corporate governance, regulatory loopholes and remedies which could serve as a guide to the corporate world.

This is just one of the examples of numerous scams and frauds of the contemporary world. The issue raises many questions pertaining to ethics, morality and our moral responsibility to others. Is Satyam scandal an atypical situation, or does it represent a disturbing trend? This case also raises important questions in relation to the general notion of morality and ethics in leadership: What is the nature of morality and why do leaders need to be ethically and morally correct? Can ethical leadership be effective? Can ethical or moral leadership be called good leadership? These are some questions which need to be debated in the present century when the world is driven by selfish motives and power for self occupies priority.

In the contemporary Indian leadership scenario, people such as Azim Premji (Chairman of Wipro Corporation), Narayan Murthy (Chief Mentor and founder of Infosys), Ratan Tata (Chairman, Tata Sons), Dr. Abdul Kalam (Former President of India) and late Dr. G. Venkatswamy (Chairman, Arvind Eye Care in Madurai), who have set a trend in ethical leading, have been much popular. They are hailed as emphatic leaders displaying certain values and beliefs and in taking part in community welfare (Robbins, 2011). For example, Wipro is perhaps the first Indian company to articulate a set of 'beliefs' to guide business conduct as early as 1970 s. The company has compiled an integrity manual which is derived from the 'Wipro values' and defines the way Wiproites should conduct business with their customers (Fernando, 2009). So is the case at Infosys; a Code of Ethics is especially formulated for the finance professionals and whistleblower's policy to encourage and protect employees willing to share information on fraud and who want to remain anonymous. Narayan Murthy has been a role model to foster an environment in ethical leading in his company. He takes care that the ideals of the company which include making the decision to commit to ethics, encouraging open communication, and being consistent in their approach. These are articulated at every available opportunity among the Infoscions. Infosys has set new records as far as communicating with the shareholders, stock exchanges, and the general public. Its annual report is believed to be trendsetter with respect to the disclosure norms. Its annual report is 
commended to be an ideal report by the Securities and Exchange Commission of the United States of America to be emulated by American companies (Fernando, 2010). He articulates his vision of a progressive society in his book A Better India, a Better World (2009), laying emphasis on good leadership and values. Dr. Abdul Kalam's ethical leading is inspired by Dr. Homi Bhabha and Vikram Sarabhai (Gandhi, 2006). As a humanist, he has always been concerned with the equitable progress in society; the vision of a developed India by 2020 has actually set a goal in all aspects of the nation and thus we have people whose vision and decision in maintaining the personal and professional fronts have shaped the fate of the nation.

\section{CONCLUSION}

Discourses concerning good and evil in the contemporary world chiefly remain relative. A few years ago, Ramalinga Raju was considered to be an ethical leader who had set standards for personal and professional ethics in decision making for his company. Today due to one significant yet inane error, his case is portrayed as one of the most villainous corporate frauds. In the case of Macbeth, he remains as a chief confidant of King Duncan till he plots the act of murder. Ambition in the process of the development of a character remains central in the way a character behaves or acts. Whether literary, metaphorical or real, our hopes and aspirations remain central in how we decide our personal and professional decisions taking good and evil into account to our judgment and action. Moreover, as has been the case both good and evil run parallel and our choice of action decides, at a later stage, the way we act upon the concept of good and evil. Literary characters such as Macbeth and Claudius, and contemporary leaders such as Ramlinga Raju remain prototypes of how a singlestep towards achieving unconditional power decides the fate of many, and this indicates, in principle, such characters-literary, historical or otherwise-have much to offer for a proper understanding in ethical leading.

\section{Notes}

${ }^{1}$ Freud discusses in detail the cause of mental disorder in Lady Macbeth in "Some CharacterTypes Met with in Psycho-Analytic Work" (1916). He focuses on her childlessness that leads to disillusionment, and further the guilt of the crime leads to mental disorder. Freud on the basis of Holinshed Chronicles (1577) asserts that though the story of Macbeth is picked by Shakespeare from the Chronicle, it is mentioned only once in the chronicle that Lady Macbeth was an ambitious wife who instigates Macbeth to murder and that is to become a queen herself. There is no further reference to her subsequent fate and of development of her character. In the same manner Freud suggests Macbeth's transformation into a bloodthirsty tyrant is because of the same reason that he could not produce an heir to the throne. In Holinshed it was around ten years that Macbeth ruled after the murder of Duncan and the account highlights his transformation into a tyrant after his realization that the prophecy of Banquo may be fulfilled as in his own case. And then he plans to murder Banquo and engages in crimes one after another as dramatised by Shakespeare in the play. Though the Chronicles do not state childlessness to be the cause of transformation, Freud claims that there are enough reasons for this to be a plausible motive of transformation.

2 Historically in the Holinshed's Chronicles, a comparison is drawn between Macbeth and Duncan. Duncan is portrayed as ruler with "soft and gentle of nature, that people wished the inclinations and maners of these two cousins to haue been so tempered and interchangeablie bestowed betwixt them, that where one had too much of clemencie, and the other of crueltie, the meane virtue betwixt these two extremities might haue reigned by indifferent partition in them both, so should Duncane haue proued a worthy king, and Makbeth an excellent capteine. The beginning of Duncans reigne was very quiet and peaceable, without anie notable trouble; but after it was perceiued how negligent he was in punishing 
offenders, manie misruled person tooke occasion thereof to trouble the peace and quiet state of the common-wealth, by seditious commotions which first had their beginnings in this wise" (Holinshed's Chronicles, vol. v, p.265).

${ }^{3}$ Holinshed's Chronicle reports Macbeth to be a just ruler: "Mackbeth shewing himself thus a most diligent punisher of all iniures and wrongs attempted by anie disordered persons within his realme, was accounted the sure defense and bucler of innocent people; and hereto he also applied his whole indeuor, to cause young men to exercise themselues in virtuous maners, and men of church to attend their diuine seruice according to their vocations" (Holinshed, 1808, vol. v, 270). He rules for about ten years after the murder of Duncan but Lady Macbeth does not produce an heir to the throne which makes him insecure and tyrannical. He is tormented by the thought as the prophecy of his kingship has come out to be true, so would be of Banquo's lineage taking up the crown. This motivates him to order the assassination of Banquo and his son Fleance. This marks the beginning of his tyrannical rule and many noble men are put to death on slight doubt and suspicion. Holinshed reports this in the Chronicles as: "After the contriued slaughter of Banquho, nothing prospered with the foresaid Makbeth: for in maner euerie man began to doubt his owne life, durst vnneth appeare in the kings presence...there were manie that stood in feare of him, so likewise stood he in feare of manie" (p.273). Shakespeare exploits some details while representing the story of Macbeth but some parts are directly picked from the Chronicles. For example, in Act IV scene iii, when Macduff pleads Malcolm to return and free Scotland from the tyrannical rule of Macbeth, Malcolm pretends to be a bad choice and will prove worse than Macbeth in order to check his loyalty and to make sure that he is not an agent of Macbeth.

\section{REFERENCES}

Adelman, Janet (1996). "Born of Woman: Fantasies of Maternal Power in Macbeth." Shakespearean Tragedy and Gender. Ed. Shirley Nelson Garner and Madelon Sprengnether. Indiana: Indiana UP. 105-135.

Allen, E.L (1963). From Plato to Nietzsche. New York: Random House.

Armitage, David, Conal Condren and Andrew Fitzmaurice (Eds.) (2009). Shakespeare and Early Modern Political Thought. Cambridge: Cambridge UP.

Asquith, Clare (2006). Shadowplay: The Hidden Politics and Coded Beliefs of William Shakespeare. New York: Public Affairs. Bernstein, Richard J. (2002). Radical Evil: A Philosophical Interrogation. Cambridge: Blackwell.

Bhandari, Bhupesh (2009). The Satyam Saga. New Delhi: Business Books.

Bloom, Harold (1998). Shakespeare: The Invention of the Human. New York: Penguin Group.

Bradley, A.C. (1905). Shakespearean Tragedy: Lectures on Hamlet, Othello, King Lear, and Macbeth. $2^{\text {nd }}$ ed. London: Macmillan. Braunmuller, A.R. (Ed.) (1997). William Shakespeare. Macbeth. Cambridge: Cambridge UP.

Burns, James Macgregor (1979). Leadership. New York: Harper Collins.

---. Business Ethics and Corporate Governance. New Delhi: Pearson, 2010.

---. Business Environment. Noida: Dorling Kindersely, 2011.

Caliyurt, Kiymet and Samuel O. Idowu (Eds.) (2012). Emerging Fraud: Fraud Cases from Emerging Economies. New York: Springer. 
Campbell, Lily Bess (2009). Shakespeare's Tragic Heroes: Slaves of Passion. Cambridge: Cambridge UP.

Ciulla, Joanne B. (2004). "Leadership Ethics: Mapping the Territory." Ethics, the Heart of Leadership. Ed. Joanne B. Ciulla. Westport: Praeger. 3-24.

Cohen, Ed. and Priscilla Nelson (2010). Riding the Tiger: Leading Through Learning in Turbulent Times. New York: ASTD.

Coursen, H.R. (1997) Macbeth: A Guide to the Play. Westport: Greenwood Press.

Desmet, Christy (1992). Rhetoric, Ethics, and Identity. Amherst: U of Massachusetts P.

Dutton, Richard, and Jean E. Howard (Eds.) (2003). A Companion to Shakespeare's Works, Vol I, Tragedies. Oxford: Blackwell.

Fernando, A.C. (2009). Business Ethics: An Indian Perspective. New Delhi: Dorling Kindersely.

Forsyth, Neil (2003). "Evil and Literature: Grandeur and Nothingness." Understanding Evil: An Interdisciplinary Approach. Ed. Margaret Sönser Breen. Amsterdam: Rodopi, pg.1-18.

Frame, Donald M. (Ed.) (1958) Michel Montaigne. The Complete Essays of Montaigne. Stanford: Stanford UP.

Freud, Sigmund (1959). The Standard Edition of the Complete Psychological Works of Sigmund Freud. Trans. \& Ed. James Strachey. London: Hogarth Press.

Gandhi, Jegadish P (2006). Dr. Abdul Kalam's Futuristic India. New Delhi: Deep and Deep Pub, 2006.

Gardener, J.W. (1990). On Leadership. New York: Free Press.

Goddard, Harold (1960). The Meaning of Shakespeare. 2 vols. London: U of Chicago P.

Greenblatt, Stephen (2004). Will in the World: How Shakespeare Became Shakespeare. New York: W.W. Norton.

Halliwell, Stephen (Ed.) (1998). Aristotle's Poetics. Chicago: U of Chicago P.

Harness, William (Ed.) (1855). "Dr. Johnson's Preface." The Complete Works of William Shakespeare Comprising his Plays and Poems. New York: Jas B. Smith and Company. 3-18.

Hughes, M.Y (Ed.) (1962). John Milton. Paradise Lost. London: Macmillan.

Johnson, J. et al. (Eds.) (1808). Raphael Holinshed. Holinshed's Chronicles of England, Scotland, and Ireland. London: n.p., 1808.

Jones, Earnest (1947). William Shakespeare's Hamlet: A Psychoanalytical Study. London: Vision Press.

Jowett, Benjamin (Ed.) (1970). The Republic. London: Sphere Books.

Kalam, A.P.J. and Y.S. Rajan (1998). India 2020: A Vision for the New Millennium. Delhi: New York.

Kant, Immanuel (1966). "Religion within the Boundaries of Mere Reason." Religion and Rational Theology. Ed. Allen Wood and George Di Giovanni. Cambridge: Cambridge UP. 39-115.

Keefer, Michael (Ed.) (2007). Marlowe, Christopher. Doctor Faustus. Toronto: Broadway.

Knights, L.C. (1946). Explorations: Essays in Criticism Mainly on the Literature of the Seventeenth Century. London: Chatto and Windos.

Knight, Wilson (1989). The Wheel of Fire: Interpretations of Shakespearean Tragedies. London: Routledge.

Legatt, Alexander (2005). Shakespeare's Tragedies: Violation and Identity. Cambridge: Cambridge UP.

Lobban, John H. (Ed.) (2009). .Hazlitt, William. Characters of Shakespeare's Plays. New York: Cambridge UP.

McAlindon, Thomas (1991). Shakespeare's Tragic Cosmos. Cambridge: Cambridge UP.

McEachern, Claire Elizabeth (2002). The Cambridge Companion to Shakespearean Tragedy. Cambridge:Cambridge UP.

Mehl, Dieter (1986). Shakespeare's Tragedies: An Introduction. Cambridge: Cambridge UP.

Meindl, J.R. (1995) “The Romance of Leadership as a Follower Centric Theory: A Social Constructionist Approach.” Leadership Quarterly $6.3: 329-41$.

Moschovakis, Nick (2008). "Introduction: Dualistic / Problematic Macbeth?" Macbeth: New Critical Essays. Ed. Nick Moschovakis. New York: Routledge. 1-72.

Onions, C.T (Ed.) (1966). "Evil.” Oxford Dictionary of English Etymology. New York: Oxford UP, pg. 332.

Richards, Angela and James Strachey (Eds.) (1900). The Interpretations of Dreams. London: Penguin.

Robbins, Stephen P. Organisational Behavior. 14th ed. Delhi: Pearson, 2011. 
Ross, David and Leselie Brown (Eds) (2009). Aristotle. Nichomachean Ethics. Oxford. Oxford UP.

Rost, Joseph C. (1991). Leadership in the Twenty-First Century. New York: Praeger.

"Satyam Chairman Ramlinga Raju's letter." Reuters. UK edition. www.uk.reuters.com. 7 Jan 2009. Web 20 April 2012.

Sharpe, Alfred (1909). "Evil.” The Catholic Encyclopedia. Vol 5. New York: Robert Appleton Company. Web 23 May 2012.

Shirley, Samuel (Ed.) (1992). B. Spinoza. Ethics: Treatise on Emendation of the Intellect and Selected Letters. London: Hackett Press.

Spencer, Theodore (2009). Shakespeare and the Nature of Man. Cambridge: Cambridge UP.

Stuab, Ervin (1989). The Roots of Evil: The Origins of Genocide and Other Group Violence. Cambridge: Cambridge UP.

Sullivan, Daniel (Ed) (2007). Aquinas, Thomas. Summa Theologica. Vol 2. New York: Cosimo Classics.

Watson, Robert N. (1984). "Foolish Wishes, and the Tragedy of Macbeth." Shakespeare and the Hazards of Ambition. Harvard: Harvard UP. 85-100.

Wells, Robin Headlam (2005). Shakespeare's Humanism. Cambridge: Cambridge UP.

Winkler, Ingo (2010). Contemporary Leadership Theories: Enhancing the Understanding of the Complexity, Subjectivity and Dynamic of Leadership. London: Sage.

Wren, Thomas J. (2006). "A Quest for a Grand Theory of Leadership." The Quest for a General Theory of Leadership. Eds. George R. Goethals and Georgia Jones Sorenson Cheltenham: Edward Elgar. 1-38.

Yukl, G.A. (1994). Leadership in Organisations. New Jersey: Prentice Hall.

Yukl, G.A. (2006). Moral Leadership: The Theory and Practice of Power, Judgment and Policy. Ed. Deborah L. Rhode. San Francisco: Wiley, 2006.

Zimansky, Curt (Ed.) (1956). The Critical Works of Thomas Rymer. New York: Yale UP.

Zimbardo, Phillip (2007). The Lucifer Effect: Understanding How Good People Turn Evil. New York: Random House. 